\title{
Response of Symbiotic Endomycorrhizal Fungi to Estrogens and Antiestrogens
}

\author{
Marie-Josée Poulin, ${ }^{1}$ Jacques Simard, ${ }^{2}$ Jean-Guy Catford, ${ }^{1}$ Fernand Labrie, ${ }^{2}$ and Yves Piché ${ }^{1}$ \\ ${ }^{1}$ Centre de Recherche en Biologie Forestière, Faculté de Foresterie et de Géomatique, Université Laval, \\ Sainte-Foy, Québec, G1K 7P4, Canada; 'Laboratoire d'Endocrinologie Moléculaire, Centre de Recherche \\ du CHUL (Centre Hospitalier de I'Université Laval), 2705 Boulevard Laurier, Québec, G1V 4G2, Canada \\ Received 22 November 1996. Accepted 14 February 1997.
}

Plant flavonoids reported previously to act as molecular signals in the arbuscular mycorrhizal (AM) symbiosis are known to bind to estrogen receptors and to exert estrogenic effects on mammalian cells. To further investigate the estrogen-like properties of flavonoids the present study examined whether estrogen and antiestrogens have flavonoid-related functions in AM fungi. Bioassays were performed in a monoaxenic system with the AM fungi Gigaspora margarita and Glomus intraradices. The plant flavonoids quercetin and biochanin A stimulate hyphal growth of $G$. margarita and $G$. intraradices, respectively. The stimulatory activity of biochanin A studied at concentrations ranging from 0.01 to $10.0 \mu \mathrm{M}$ shows an estimated $\mathrm{EC}_{50}$ value of $3.26 \mu \mathrm{M}$. The present results show that $17 \beta$ estradiol and biochanin A exert similar stimulatory effects in $G$. intraradices. The agonist effect of biochanin A was efficiently suppressed by the new antiestrogen EM-652, which is also consistent with the possible presence of estrogen-binding sites in AM fungi.

Additional keywords: estrogenic activity.

Arbuscular mycorrhizal (AM) fungi form the most fundamental and universal "fungus-root" symbiosis. Fossil records suggest that this fungus-plant association was first established over 400 million years ago (Simon et al. 1993; Remy et al. 1994). These mutualistic fungi colonize most vascular plants, including many economically important forest and crop species. They play a major role in enhancing plant growth by providing nutrient and water uptake from soil outside of the root's depletion zone. AM fungi may also reduce plant susceptibility to soilborne pathogens (Jalali and Jalali 1991). However, AM fungi are obligate biotrophs that cannot be cultivated away from the host plants. The growth of AM fungi in pure culture in the absence of host roots is considered a prerequisite to fully understanding and manipulating AM symbioses and is one of the greatest challenges in plant science.

Driven by the need to understand the biology of AM fungi, we have developed a simple and reproducible method that uses root organ cultures genetically transformed by the Ri T-DNA

Corresponding author: Y. Piché; E-mail: ypiche@rsvs.ulaval.ca

Present address of Marie-Josée Poulin: Science Design, 1455 Avenue O’Neil, Québec, Canada. G1P-2G8. plasmid of Agrobacterium rhizogenes as the plant partner for the axenic culture of the AM fungi Gigaspora margarita and Glomus intraradices (Bécard and Piché 1992). This in vitro system has allowed the identification of some factors produced by roots that regulate AM fungal growth (Bécard and Piché 1989a). Moreover, Bécard and Piché (1989b) showed that the stimulation of hyphal growth in G. margarita requires a synergistic interaction between root exudates and carbon dioxide when co-cultured with Ri T-DNA-transformed carrot roots.

Commercially available flavonoids promote spore germination and hyphal growth of G. margarita (Gianinazzi-Pearson et al. 1989). Flavonoids naturally released from host roots enhance hyphal growth of the AM fungus Glomus etunicatum (Tsai and Phillips 1991) and promote AM colonization in other Glomus spp. (Nair et al. 1991). We isolated and identified flavonols (quercetin, kaempferol, and morin) from Ri TDNA-transformed (Bel-Rhlid et al. 1993) and nontransformed (Poulin et al. 1993) carrot roots. These flavonols are known to stimulate the hyphal growth of G. margarita (Bécard et al. 1992; Chabot et al. 1992a). However, AM fungal growth responses to root flavonoids are not uniform (Nair et al. (1991). Isoflavones such as biochanin A that stimulate hyphal growth of Glomus spp., inhibit G. margarita (Bécard et al. 1992; Chabot et al. 1992a). Several aspects of the role of root exudates and flavonoids in AM formation have been reviewed (Mandelbaum and Piché, in press; Vierheilig et al., in press).

Root phenolics are a widespread class of secondary metabolites that are known to play an important role in plantmicrobial interactions (Siqueira et al. 1991; Rhodes 1994). Phenolic signals are involved in the induction of virulence (vir) genes in Agrobacterium (Stachel et al. 1986) and nodulation (nod) genes in Rhizobium and Bradyrhizobium (Long 1989). Moreover, various secondary metabolites are molecular signals for haustorial formation in Striga, a parasitic angiosperm (Lynn and Chang 1990), and for pollen tube development in Petunia spp. (Vogt et al. 1994).

Flavonoids are also known for their estrogenic activity in vertebrates. The infertility induced in Australian sheep by clover isoflavonoids is a well-known example (Bennetts et al. 1946; Findlay et al. 1973). Flavonoids bind to estrogen receptors and have agonist estrogenic activity (for a review, see Miksicek 1993a). However, they are less active, on a molar basis, than the most biologically active estrogen (17 $\beta$ estradiol). Evidence of the hormone-like activity exhibited by flavonoids has been confirmed by the suppression of its effect 
<smiles>O=c1c(O)c(-c2ccc(O)c(O)c2)oc2cc(O)cc(O)c12</smiles>

Quercetin

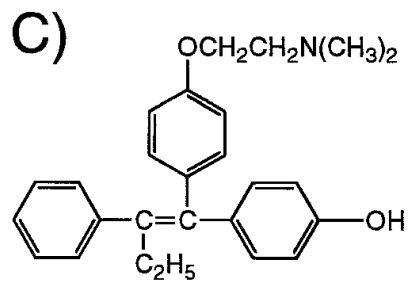

OH-Tamoxifen<smiles>COc1ccc(-c2coc3cc(O)cc(O)c3c2=O)cc1</smiles>

Biochanin A<smiles>[R7][C@H]1Cc2cc(O)ccc2[C@H]2CC[C@@]3(C)[C@@H](C[C@H](Cl)[C@@H]3O)[C@H]12</smiles>

EM-139

$\mathrm{R}_{7}=\left(\mathrm{CH}_{2}\right)_{10} \mathrm{CONnBuMe}$

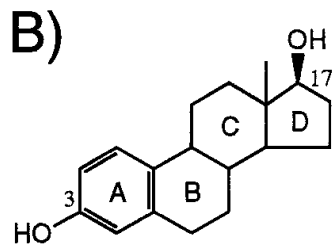

17ß-estradiol

Fig. 1. Chemical structures of (A) quercetin and biochanin A, (B) the estrogen 17ß-estradiol, and (C) the antiestrogens OH-tamoxifen, EM-139, and EM-652 used in this study.

in mammalian cells by antiestrogens (Markiewicz et al. 1993; Miksicek 1993a).

In order to gain further insights into the sequence of transcriptional events taking place during endomycorrhizal fungal growth, the present study investigated whether flavonoids might mimic an estrogen-like function in endomycorrhizal fungi. In vitro bioassays were performed to test the effect of mammalian estrogen agonist and antagonist compounds on AM fungi. The data show that flavonoid action on fungal growth can be blocked by pure antiestrogens, thus suggesting an estrogen-like effect of flavonoids in AM fungi.

\section{RESULTS}

Effect of the antiestrogens OH-tamoxifen and EM-139 on the stimulatory effect of quercetin on hyphal growth of G. margarita.

When compared with the control, quercetin (Fig. 1) induced a significant stimulation of hyphal growth in G. margarita during the course of the experiment (Fig. 2). The antiestrogen $\mathrm{OH}$-tamoxifen $(5.0 \mu \mathrm{M})$ (Fig. 1) significantly reduced the stimulatory effect of quercetin (Fig. 2). However, when applied in the absence of quercetin an inhibition of hyphal growth was also observed (Fig. 2). OH-tamoxifen at a concentration of $0.5 \mu \mathrm{M}$, alone or in combination with quercetin, produced no significant effect on hyphal growth (Fig. 2). The pure antiestrogen EM-139 $(5.0 \mu \mathrm{M})$ significantly inhibited the stimulatory effect of quercetin while alone it showed no effect on hyphal growth (Fig. 3).

\section{Growth curve of $G$. intraradices in the presence} of different concentrations of biochanin $A$.

At lower concentrations of biochanin A $(0.01,0.05,0.1$, and $1.0 \mu \mathrm{M}$ : open dots on the growth curve; Fig. 4) the rate of hy-

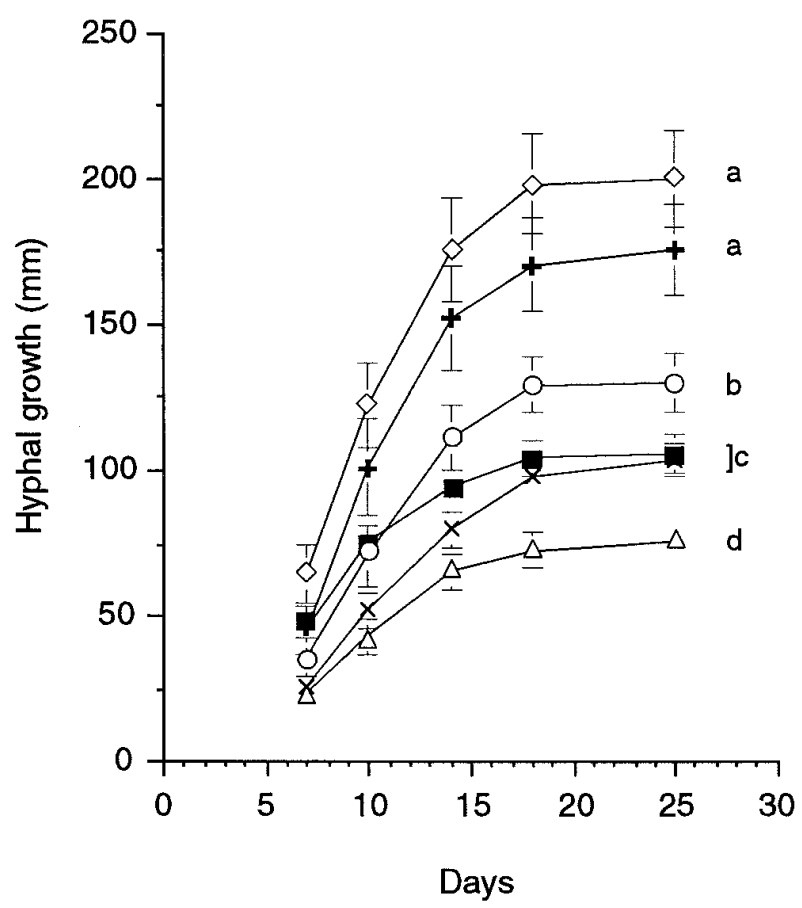

Fig. 2. Hyphal growth of Gigaspora margarita in the presence of quercetin $(5.0 \mu \mathrm{M})(\diamond)$, quercetin $(5.0 \mu \mathrm{M})+\mathrm{OH}-\mathrm{Tam}(0.5 \mu \mathrm{M})(\mathbf{+})$, quercetin $(5.0 \mu \mathrm{M})+\mathrm{OH}-\mathrm{Tam}(5.0 \mu \mathrm{M})(\mathrm{O})$, OH-Tam $(0.5 \mu \mathrm{M})(\mathrm{x})$, OH-Tam $(5.0 \mu \mathrm{M})(\Delta)$, control $(\square)$. Curves with different letters have significantly different final values for hyphal growth (Waller-Duncan test, $P<0.05$ ).

phal growth is not significantly different from that of the control. However, at higher biochanin A concentrations (4.0, 5.0, 7.5, and $10.0 \mu \mathrm{M}$ : black dots on the growth curve; Fig. 4) a 
significant stimulatory effect was observed. The curve tapers off in the presence of the highest concentration used (10.0 $\mu \mathrm{M})$. The calculated $\mathrm{EC}_{50}$ value is $3.26 \pm 0.47 \mu \mathrm{M}$.

\section{Effect of the antiestrogen EM-652 on the stimulatory effect of biochanin $A$ on the hyphal growth of $G$. intraradices.}

Biochanin A alone at a concentration of $3.26 \mu \mathrm{M}$ results in a hyphal length of $316 \mathrm{~mm}$ (open square box; Fig. 5). Low concentrations of EM-652 (1.0, 2.0, and $3.26 \mu \mathrm{M}$ : open dots on the growth curve; Fig. 5) in combination with biochanin A resulted in a hyphal length not significantly different from that of biochanin A alone. A significant decrease in hyphal length was measured at EM-652 concentrations ranging from 7.5 to $12.0 \mu \mathrm{M}$ (black dots on the growth curve; Fig. 5). At these high concentrations of EM-652, hyphal length values were not significantly different from that of the control. EM-652 when applied alone has no significant effect on hyphal growth of $G$. intraradices, when compared with the control (data not shown).

\section{Hyphal growth of $G$. intraradices in the presence of $17 \beta$-estradiol and biochanin $A$.}

As shown in Figure 6, 17 $\beta$-estradiol $(5.0 \mu \mathrm{M})$ and biochanin A $(5.0 \mu \mathrm{M})$ stimulate hyphal growth from day 9 . At the end of the experiment, the growth-promoting effect of $17 \beta$-estradiol was not significantly different from that of biochanin A. At the end of the experiment, hyphal growth in the presence of $17 \beta$-estradiol was significantly (2.4-fold) higher than hyphal growth of the control, whereas hyphae were stimulated more

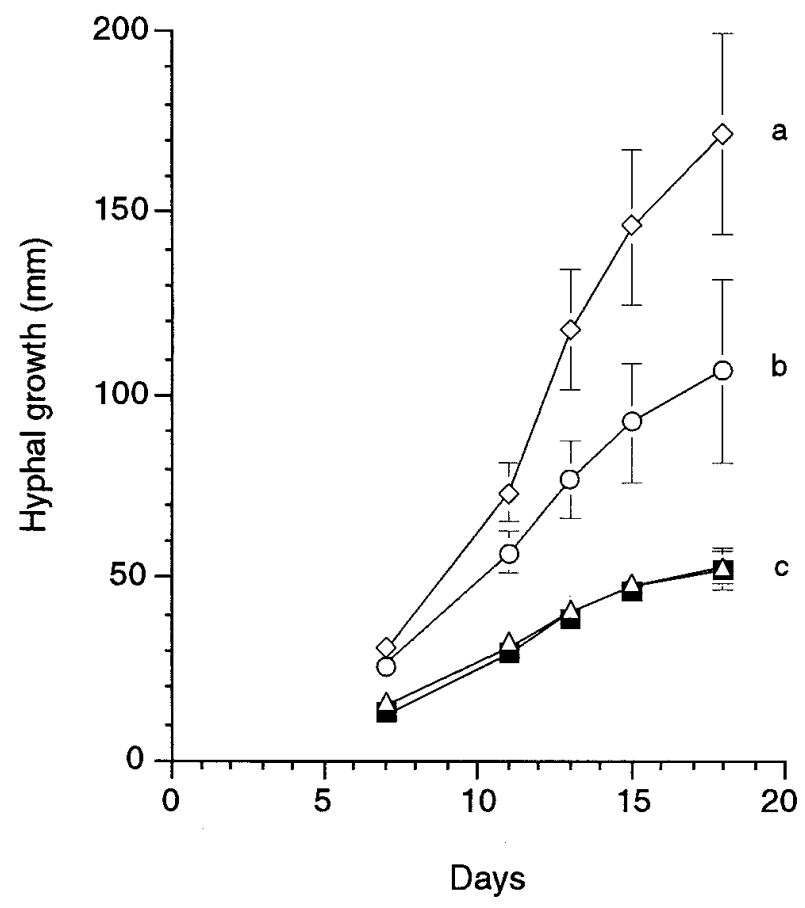

Fig. 3. Hyphal growth of Gigaspora margarita in the presence of quercetin alone $(5.0 \mu \mathrm{M})(\diamond)$ or in combination with EM-139 $(5.0 \mu \mathrm{M})(\mathrm{O})$, EM-139 alone $(5.0 \mu \mathrm{M})(\Delta)$, and the control treatment $(\mathbf{\square})$. Curves with different letters have significantly different final values for hyphal growth (Waller-Duncan test, $P<0.05$ ). than 3.3-fold in the presence of biochanin A. 17ß-estradiol at 0.5 and $1.0 \mu \mathrm{M}$ had no significant effect on hyphal growth. The highest growth rate period appeared between day 7 and 14 for all of the treatments (data not shown).

\section{DISCUSSION}

Recently, an experimental system with isolated roots genetically transformed by the Ri T-DNA plasmid of Agrobacterium rhizogenes and subsequently inoculated with AM fungal spores has given new impetus to the study of root factors involved in symbiotic mycorrhizal interactions (Bécard and Piché 1992). This axenic system allows direct and nondestructive measurements of AM hyphal growth stimulation under the influence of root-derived stimuli, such as flavonoids and carbon dioxide (Bel-Rhlid et al. 1993; Poulin et al. 1993). However, the exact mechanisms by which such flavonoids contribute to the marked stimulation in hyphal growth of AM fungi are poorly understood, and contradictory results (Bécard et al. 1995) suggest that they are not necessarily signaling compounds involved in AM symbioses.

However, the view that flavonoids from the plant phenylpropanoid pathway are transcriptional signals for many soil microorganisms (Phillips 1992) and the fact that flavonoids also have the capacity to activate transcription factors in mammalian cells (Markaverich et al. 1988; Markiewicz et al. 1993; Miksicek 1993a, 1993b; Whitten and Naftolin 1991) suggest the need to re-evaluate the putative role of flavonoids as molecular signals in plant-fungal symbioses.

Baker (1992a, 1992b) suggested that the biological activity of phytoestrogens (flavonoids) and their steroid-like ac-

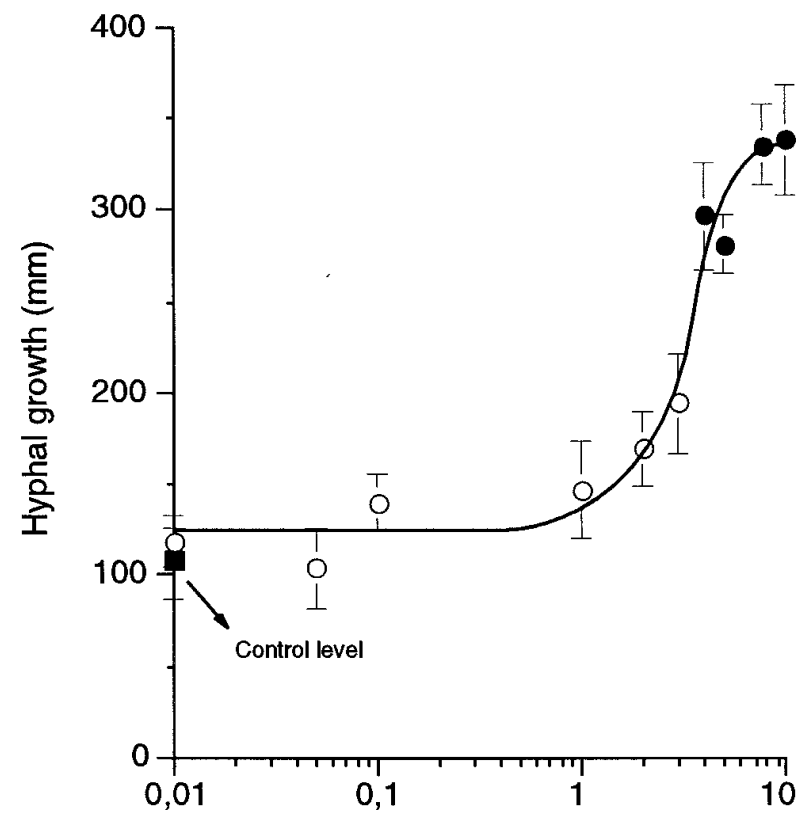

Concentration of biochanin $A(\log \mu \mathrm{M})$

Fig. 4. Dose response curve showing hyphal growth of Glomus intraradices in relation to biochanin A $(0.01$ to $10 \mu \mathrm{M})$. Total hyphal length was measured after 28 days. Values represented by black dots are significantly different from the control level (Tukey, $P<0.05$ ). 
tions in vertebrates could have similarities with the actions of the phenolic signals that mediate legume-Rhizobia symbiosis. These similarities pertain to the exchange of molecular mediators, their functions, and also the structure of their ligand-binding regions. $17 \beta$-estradiol and some flavonoids can interact, respectively, with Nod D proteins in Rhizobium and estrogen receptors in vertebrates (Györgypal and Kondorosi 1991). From an evolutionary perspective, Baker (1992a, 1992b, 1995) reported the existence of homology between polypeptide modules located in binding proteins found in Rhizobium and various steroidmetabolizing enzymes, suggesting that these proteins originate from a common ancestor (Baker 1992a, 1992b; Györgypal and Kondorosi 1991). Interestingly, estrogen-binding proteins have been identified in yeast and bacteria (for a review see Baker 1995). Brann et al. (1995) showed that the principal mode of action of antiestrogens in mammals is to bind specifically to estrogen receptors without the transformation of the bound receptor. Therefore, in an initial experiment, we used antiestrogens to block the effect exerted by stimulatory flavonoids on AM hyphal growth.

The introductory experiments with $\mathrm{OH}$-tamoxifen, a commercially available mixed antiestrogen compound, resulted in an inhibition of the stimulatory effects of quercetin on hyphal growth in Gigaspora margarita. However, when used in isolation, high concentrations of $\mathrm{OH}$-tamoxifen exert inhibitory effect on hyphal growth in G. margarita. The use of a pure, more specific, antiestrogen, EM-139, significantly reversed the stimulatory effect of quercetin without creating an inhibi-

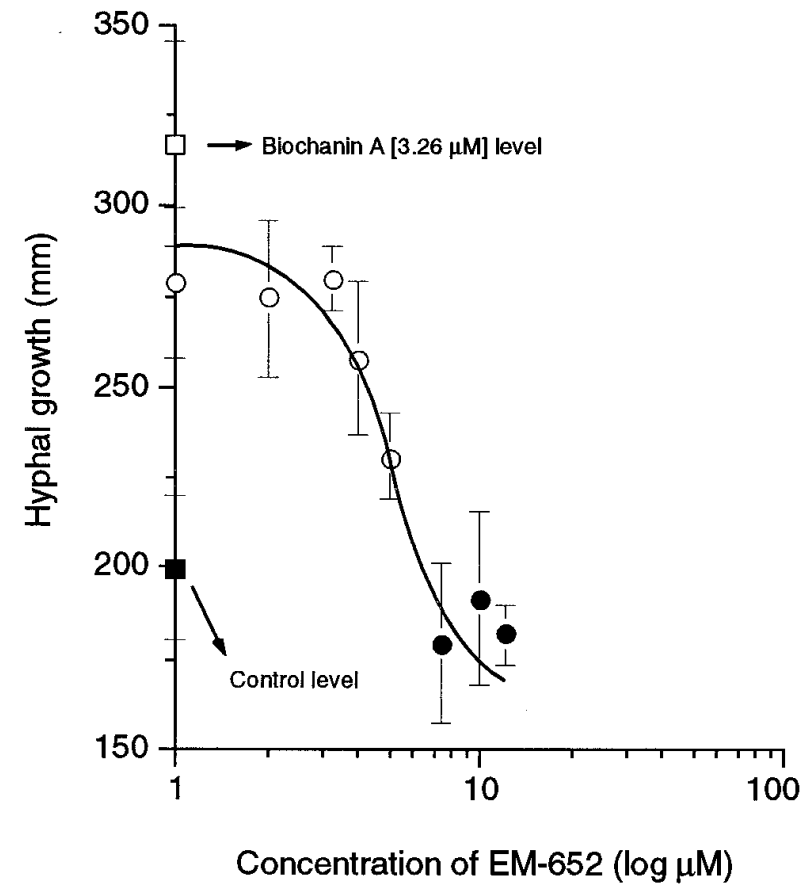

Fig. 5. Effects of the antiestrogen EM-652 (1.0 to $12.0 \mu \mathrm{M})$ in combination with biochanin A $(3.26 \mu \mathrm{M})$ on hyphal growth of Glomus intraradices. Total hyphal length was measured after 28 days of culture. Biochanin A level is the measure of hyphal growth in the presence of biochanin A $(3.26 \mu \mathrm{M})$ alone. Hyphal growth values represented by black dots are significantly different from the biochanin A level (Tukey, $P<0.05)$ tion on hyphal growth when used alone. These results provide a new and exciting insight into the potential role of flavonoids on AM fungal growth.

In this study $G$. intraradices was used to determine whether estrogen-like binding sites exist in AM fungi. We established a dose-response curve $(0.01$ to $10.0 \mu \mathrm{M})$ that shows that biochanin A stimulates hyphal growth of $G$. intraradices, as previously reported by Nair et al. (1991) at the concentration of 5 ppm. Interestingly, Siqueira et al. (1991) showed that biochanin A has a positive, concentration-dependent effect on clover root colonization by $G$. intraradices. Although specific molecular mechanisms underlying AM establishment remain to be elucidated, recent results suggest that isoflavones are important signal molecules (Nair et al. 1991) that may stimulate AM system by altering gene expression during endomycorrhizal development (Fries et al. 1996; Ozan et al. 1996).

To demonstrate the possible presence of estrogen-like binding sites in $G$. intraradices we used EM-652, the most efficient antiestrogen available (Labrie et al. 1996; Simard et al. 1996). Since EM-652 alone has no significant effect on hyphal growth, we suggest that the inhibitory effect induced by the simultaneous presence of EM-652 and biochanin A results from the capacity of EM-652 to effectively compete for flavonoid binding sites in $G$. intraradices.

In addition, our results show that the mammalian estrogen (17 $\beta$-estradiol) stimulates hyphal growth of $G$. intraradices. Taken together with previous observations, the present data provide, to the best of our knowledge, the first evidence for the potential presence of estrogen-like binding sites in $G$. intraradices. We propose that these sites are activated by plant

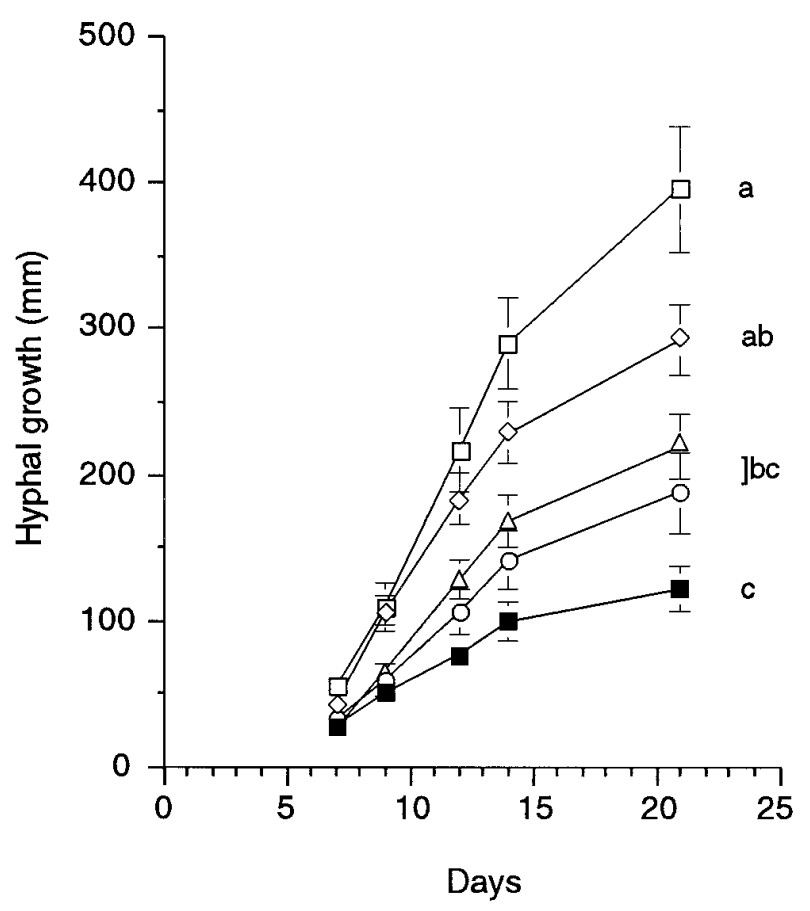

Fig. 6. Hyphal growth of Glomus intraradices in the presence of biochanin A $(5.0 \mu \mathrm{M})(\square), 17 \beta$-estradiol $(5.0 \mu \mathrm{M})(\diamond),(0.5 \mu \mathrm{M})(\Delta),(1.0$ $\mu \mathrm{M})(\mathrm{O})$, and the control treatment (ם). Curves with different letters have significantly different final values for hyphal growth (Tukey, $P<$ $0.05)$. 
flavonoids that serve as molecular signals for the induction of enhanced fungal growth.

The planar ring system $\mathrm{A}$ and $\mathrm{C}$ of biochanin $\mathrm{A}$ (Fig. 1) and the corresponding rings $\mathrm{A}$ and $\mathrm{B}$ of $17 \beta$-estradiol (Fig. 1), together with the hydroxyl group located at position $\mathrm{C}-7$ of the isoflavone nucleus corresponding to the position $\mathrm{C}-3$ of the $17 \beta$-estradiol ring system, result in a structural resemblance between the two molecules. Nair et al. (1991) showed the presence of this hydroxyl group in biochanin A to be one of the essential features of the molecule responsible for its stimulatory effect on hyphal growth in $G$. intraradices. The presence of a similar group in $17 \beta$-estradiol might explain the stimulatory effect of this compound.

Additional studies are needed to provide further insight into the biological activities of plant flavonoids and mammalian steroids in order to characterize potential similarities in their respective signal transduction pathways.

\section{MATERIALS AND METHODS}

\section{Fungal material.}

Spores of Gigaspora margarita Becker \& Hall (DAOM 194757, Biosystematic Research Center, Ottawa, Canada) were isolated from a leek (Allium porrum L.) pot culture by wet sieving followed by gradient centrifugation (Furlan et al. 1980). Spores were surface sterilized (Bécard and Fortin 1988 ) and stored in a mixture of $0.02 \%$ (wt/vol) streptomycin sulfate and $0.01 \%(\mathrm{wt} / \mathrm{vol})$ gentamycin sulfate solution at $4{ }^{\circ} \mathrm{C}$ until used. Spores of Glomus intraradices Smith \& Schenck (DAOM 197198, deposited at the Biosystematic Research Center, Ottawa, Canada) were routinely obtained from in vitro dual culture with tomato roots (Lycopersicon esculentum Mill. var. Vendor) (Chabot et al. 1992b). Spores of G. intraradices and G. margarita were selected with the aid of a WILD M3Z stereo microscope according to visual features (light colored, globule filled).

\section{Chemicals.}

Biochanin A, quercetin, and 17 $\beta$-estradiol were purchased from Sigma Chemical Co. (St. Louis, MO). 4-OH-tamoxifen was kindly provided by D. Salin-Drouin, Besino-Iscovesco (Paris, France). The pure antiestrogens EM-139 (Labrie et al. 1992; Lévesque et al. 1991) and EM-652 (Labrie et al. 1996; Simard et al. 1996) were provided by the Laboratoire d'Endocrinologie Moléculaire, Centre de Recherche du CHUL (Québec, Canada). Structures of flavonoids and estrogenic compounds used in the present study are depicted in Figure 1 . The stock solutions $(0.03 \mathrm{M})$ of all of these substances were prepared in $95 \%$ ethanol.

\section{Culture medium.}

All experiments were carried out in minimal (M) White's medium under sterile conditions (Bécard and Fortin 1988). This medium contained the following in 1 liter of distilled water: $\mathrm{MgSO}_{4} \cdot 7 \mathrm{H}_{2} \mathrm{O}, 731 \mathrm{mg} ; \mathrm{KNO}_{3}, 80 \mathrm{mg} ; \mathrm{KCl}, 65 \mathrm{mg}$; $\mathrm{KH}_{2} \mathrm{PO}_{4}, 4.8 \mathrm{mg} ; \mathrm{Ca}\left(\mathrm{NO}_{3}\right)_{2} \cdot 4 \mathrm{H}_{2} \mathrm{O}, 288 \mathrm{mg}$; NaFeEDTA, 8 $\mathrm{mg}$; KI, $0.75 \mathrm{mg} ; \mathrm{MnCl}_{2} \cdot 4 \mathrm{H}_{2} \mathrm{O}, 6 \mathrm{mg} ; \mathrm{ZnSO}_{4} \cdot 7 \mathrm{H}_{2} \mathrm{O}, 2.65 \mathrm{mg}$; $\mathrm{H}_{3} \mathrm{BO}_{3}, 1.5 \mathrm{mg} ; \mathrm{CuSO}_{4} \cdot 5 \mathrm{H}_{2} \mathrm{O}, 0.13 \mathrm{mg} ; \mathrm{Na}_{2} \mathrm{MoO}_{4} \cdot 2 \mathrm{H}_{2} \mathrm{O}$, $0.0024 \mathrm{mg}$; glycine, $3 \mathrm{mg}$; thiamine, $0.1 \mathrm{mg}$; pyridoxine, 0.1 $\mathrm{mg}$; nicotinic acid, $0.5 \mathrm{mg}$; myo-inositol, $50 \mathrm{mg}$; sucrose, 10 g. The medium was solidified with $0.5 \%$ gellan gum (ICN
Biochemicals, Cleveland, $\mathrm{OH}$ ). The $\mathrm{pH}$ was adjusted to 5.5 before sterilization at $121^{\circ} \mathrm{C}$ for $16 \mathrm{~min}$.

\section{Incubation of the axenic cultures.}

Previous studies have shown that AM hyphal growth is stimulated in a $\mathrm{CO}_{2}$-enriched environment (Bécard and Piché 1989b). The optimal concentration has been determined to be around $2.0 \%$ (Poulin et al.1993) and therefore all experiments in this study were performed at this concentration.

\section{Effect of the antiestrogens OH-tamoxifen and EM-139 on hyphal growth of $\boldsymbol{G}$. margarita stimulated by quercetin.}

Quercetin $(5.0 \mu \mathrm{M})$ alone or in combination with the antiestrogen $\mathrm{OH}$-tamoxifen $(0.5 \mu \mathrm{M}, 5.0 \mu \mathrm{M})$ or EM-139 $(5.0 \mu \mathrm{M})$ was added aseptically to the culture medium. Antiestrogens were also tested alone at the same concentrations. Control treatment contained $0.05 \%$ ethanol. Previous results showed no effect of ethanol on hyphal growth at this concentration. The supplemented $\mathrm{M}$ medium was poured into square petri dishes $(100 \times 15 \mathrm{~mm})$. Five spores were inserted $2.0 \mathrm{~mm}$ into the solidified medium to prevent hyphae growing out of the medium during the course of the experiment. Two sterile cotton rolls (dental rolls; Healthco DDI, Montréal) were placed at the basal side of the petri dish to absorb excess moisture. Petri dishes were covered, sealed on two sides with Parafilm, and incubated at $27^{\circ} \mathrm{C}$ in the dark. Because of the negative geotropic growth of AM fungal hyphae (Watrud et al. 1978) the petri dishes were kept vertical. The experiment was conducted twice, using a randomized complete block design comprising 8 blocks. Experimental data were statistically analyzed by analysis of variance followed by a Waller-Duncan multiple comparison test $(P<0.05)$.

\section{Growth curve of $G$. intraradices in the presence of various concentrations of biochanin $A$.}

Biochanin A was added aseptically to the culture medium to yield final concentrations ranging from 0.01 to $10 \mu \mathrm{M}$. Control treatments contained $0.05 \%$ ethanol. Fifteen spores of $G$. intraradices were inserted in the center of each petri dish $(10 \times$ $100 \mathrm{~mm}$ ) and incubated at $27^{\circ} \mathrm{C}$ in the dark. The $\mathrm{EC}_{50}$ value (the concentration of biochanin A exerting one-half of the maximal increase in hyphal growth) was calculated with a computer-assisted $\mathrm{EC}_{50} 1.01$ program, according to Marquardt (1963). This experiment was conducted twice, using a randomized complete block design comprising 10 blocks and 11 treatments. Cumulative hyphal growth emerging from these spores was considered as a single observation. Experimental data were statistically analyzed by analysis of variance followed by a Tukey's test $(P<0.05)$.

\section{Effect of the antiestrogen, EM-652, on hyphal growth of $G$. intraradices in the presence of biochanin A.}

Biochanin A $(3.26 \mu \mathrm{M})$ alone, or in combination with EM$652(1.0,2.0,3.3,4.0,5.0,7.5,10.0$, or $12.0 \mu \mathrm{M})$ was added aseptically to the culture medium. The control contained $0.05 \%$ ethanol. Fifteen spores were placed in each petri dish $(10 \times 100 \mathrm{~mm})$ and incubated at $27^{\circ} \mathrm{C}$ in the dark. The experiment was conducted once, using a randomized complete block design comprising 9 blocks. The experimental data were analyzed by analysis of variance followed by a Tukey's test $(P$ $<0.05)$. 


\section{Effect of 17 $\beta$-estradiol and biochanin A on the hyphal growth of $\boldsymbol{G}$. intraradices.}

$17 \beta$-estradiol was added aseptically to the culture medium to yield final concentrations of $0.5,1.0$, and, $5.0 \mu \mathrm{M}$. The biochanin A concentration used was $5.0 \mu \mathrm{M}$. The control contained $0.05 \%$ ethanol. Fifteen spores of $G$. intraradices were placed in each petri dish and incubated at $27^{\circ} \mathrm{C}$ in the dark. The experiment was conducted twice, using a randomized complete block design comprising 8 blocks and five treatments. Cumulative hyphal growth emerging from 15 spores in each block was considered as a single observation. Experimental data were analyzed by analysis of variance followed by a Tukey's test $(P<0.05)$.

\section{Assessment of fungal growth.}

The linear growth of hyphae emerging from germinating spores of G. margarita and G. intraradices was observed under a WILD M3Z stereo microscope and measured by the grid-line intersect method (Bécard and Piché 1989a). The first data were recorded 7 days after placement and subsequent observations were made at intervals of 3 to 4 days until hyphal growth stopped.

\section{ACKNOWLEDGMENTS}

We thank Horst Vierheilig, Robert Chênevert, Andrew Coughlan, and Boovaraghan Balaji for their critical review of this manuscript. We also wish to thank Sylvain Boisclair for the statistical analysis and Yves Mérand for helpful discussion. This research was financially supported by the Medical Research Council (Canada) and Natural Sciences and Engineering Research Council (Canada) through grants to J. S. and Y. P., respectively.

\section{LITERATURE CITED}

Baker, M. E. 1992a. Similarities between legume-Rhizobium communication and steroid-mediated intercellular communication in vertebrates. Can. J. Microbiol. 38:541-547.

Baker, M. E. 1992b. Evolution of regulation of steroid-mediated intercellular communication in vertebrates: insights from flavonoids, signals that mediate plant-Rhizobia symbiosis. J. Steroid Biochem. Mol. Biol. 41:301-308.

Baker, M. E. 1995. Endocrine activity of plant-derived compounds: An evolutionary perspective. Proc. Soc. Exp. Bio. Med. 208:131-138.

Bécard, G., Douds, D. D., Jr., and Pfeffer, P. E. 1992. Extensive in vitro hyphal growth of vesicular-arbuscular mycorrhizal fungi in the presence of $\mathrm{CO}_{2}$ and flavonols. Appl. Environ. Microbiol. 58:821-825.

Bécard, G., and Fortin, J. A. 1988. Early events of vesicular-arbuscular mycorrhiza formation on Ri T-DNA transformed roots. New Phytol. 108:211-218.

Bécard, G., and Piché, Y. 1989a. New aspects on the acquisition of biotrophic status by a vesicular-arbuscular mycorrhizal fungus, Gigaspora margarita. New Phytol. 112:77-83.

Bécard, G., and Piché, Y. 1989b. Fungal growth stimulation by $\mathrm{CO}_{2}$ and root exudates in vesicular-arbuscular mycorrhizal symbiosis. Appl. Environ. Microbiol. 55:2320-2325.

Bécard, G., and Piché, Y. 1992. Establishment of VA mycorrhizae in root organ culture: Review and proposed methodology. Pages 89-108 in: Techniques for the Study of Mycorrhiza, Vol. 24. J. R. Norris, D. J. Read, and A. K. Varma, eds. Academic Press, London.

Bécard, G., Taylor, L. P., Douds, D. D., Jr., Pfeffer, P. E., and Doner, L. W. 1995. Flavonoids are not necessary plant signal compounds in arbuscular mycorrhizal symbioses. Mol. Plant-Microbe Interact. 8:252-258.

Bel-Rhlid, R., Chabot, S., Piché, Y., and Chênevert, R. 1993. Isolation and identification of flavonoids from Ri-T-DNA transformed roots (Daucus carota) and their significance in vesicular-arbuscular mycorrhiza. Phytochemistry 33:1369-1371.
Bennetts, H. W., Underwood, E. J., and Shier, F. L. 1946. A specific breeding problem of sheep on subterranean clover pastures in Western Australia. Aust. Vet. J. 22:2-12.

Brann, D. W., Hendry, L. B., and Mahesh, V. B. 1995. Emerging diversities in the mechanism of action of steroid hormones. J. Steroid Biochem. Mol. Biol. 52:113-133.

Chabot, S., Bécard, G., and Piché, Y. 1992b. Life cycle of Glomus intraradix in root organ culture. Mycologia 84(3):315-321.

Chabot, S., Bel-Rhlid, R., Chênevert, R., and Piché, Y. 1992a. Hyphal growth promotion in vitro of the VA mycorrhizal fungus, Gigaspora margarita Becker \& Hall, by the activity of structurally specific flavonoid compounds under $\mathrm{CO}_{2}$-enriched conditions. New Phytol. 122: 461-467.

Findlay, J. K., Buckmaster, J. M., Chamley, W. A., Cumming, I. A., Hearnshaw, H., and Goldin, J. R. 1973. Release of luteinising hormone by estradiol-17ß and a gonadotrophin releasing hormone in ewes affected with clover disease. Neuroendocrinology 11:57-66.

Fries, L. L. M., Pacovsky, R. S., and Safir, G. R. 1996. Expression of isoenzymes altered by both Glomus intraradices colonization and formononetin application in corn (Zea mays L.) roots. Soil Biol. Biochem. 8:981-988.

Furlan, V., Bartschi, H., and Fortin, J. A. 1980. Media for density gradient extraction of endomycorrhizal spores. Trans. Br. Mycol. Soc. 75: 336-338.

Gianinazzi-Pearson, V., Branzanti, B., and Gianinazzi, S. 1989. In vitro enhancement of spore germination and early hyphal growth of a vesicular-arbuscular mycorrhizal fungus by host root exudates and plant flavonoids. Symbiosis 7:243-255.

Györgypal, Z., and Kondorosi, A. 1991. Homology of the ligandbinding regions of Rhizobium symbiotic regulatory protein Nod D and vertebrate nuclear receptors. Mol. Gen. Genet. 226:337-340.

Jalali, B. L., and Jalali, I. 1991. Mycorrhiza in plant disease control. Pages 131-154 in: Handbook of Applied Mycology. Vol. 1, Soil and Plants. Marcel Dekker, New York.

Labrie, F., Leblanc, G., Gauthier, S., Singh, S. M., Provencher, L., Li, X., and Mérand, Y. 1996. Binding characteristics of the pure antiestrogens EM-652 and EM-800 to the human estrogen receptor. Page 605, P2-801 in: Int. Congr. Endocrynol., 10th..

Labrie, C., Martel. C., Dufour, J.-M., Lévesque, C., Mérand, Y., and Labrie, F. 1992. Novel compounds inhibit estrogen formation and action. Cancer Res. 52:610-615.

Lévesque, C., Mérand, Y., Dufour, J.-M., Labrie, C., and Labrie, F. 1991. Synthesis and biological activity of new halo-steroidal antiestrogens. J. Med. Chem. 43:1624-1630.

Long, S. R. 1989. Rhizonium-legume nodulation: Life together in the underground. Cell 56:203-214.

Lynn, D. G., and Chang, M. 1990. Phenolic signals in cohabitation: Implications for plant development. Annu. Rev. Plant Physiol. Plant Mol. Biol. 41:497-526.

Mandelbaum, C. I., and Piché, Y. The role of exudates in arbuscular mycorrhizal initiation. In: Mycorrhizal Biology. K. G. Mukerji and B. P. Chamola, eds. Kluwer Academic Pub., Dordrecht, The Netherlands. (In press.)

Markaverich, B. M., Roberts, R. R., Alejandro, M. A., Gregory, A., Middleditch, B. S., and Clark, J. H. 1988. Bioflavonoid interaction with rat uterine type II binding sites and cell growth inhibition. J. Steroid Biochem. Mol. Biol. 36:71-78.

Markiewicz, L., Garey, J., Adlercreutz, H., and Gurpide, E. 1993. In vitro bioassays of non-steroidal phytoestrogens. J. Steroid Biochem. Mol. Biol. 45:399-405.

Marquardt, D. W. 1963. An algorithm for least squares estimation of non-linear parameters. J. Soc. Ind. Appl. Math. 11:431-441.

Miksicek, R. J. 1993a. Commonly occurring plant flavonoids have estrogenic activity. Mol. Pharmacol. 44:37-43.

Miksicek, R. J. 1993b. In situ localization of the estrogen receptor in living cells with the fluorescent phytoestrogen coumestrol. J. Histochem. Cytochem. 41(6):801-810.

Nair, M. G., Safir, G. R., and Siqueira, J. O. 1991. Isolation and identification of vesicular-arbuscular mycorrhiza stimulatory compounds from clover (Trifolium repens) root. Appl. Environ. Microbiol. 57: 434-439.

Ozan, A., Safir, G. R., and Nair, M. G. 1996. Isoenzyme activity of developing Trifolium-Glomus mycorrhiza and associated effects of the isoflavone formononetin. Allelopathy J. 3:217-228. 
Phillips, D. A. 1992. Flavonoids: Plant signals to soil microbes. Pages 201-231 in: Phenolic Metabolism in Plants, Vol. 26. H. A. Stafford and R. K. Ibrahim, eds. Plenum Press, New York.

Poulin, M. J., Bel-Rhlid, R., Piché, Y., and Chênevert, R. 1993. Flavonoids released by carrot (Daucus carota) seedlings stimulate hyphal development of vesicular-arbuscular mycorrhizal fungi in the presence of optimal $\mathrm{CO}_{2}$ enrichment. J. Chem. Ecol. 19:2317-2327.

Remy, W., Taylor, T. N., Hass, H., and Kerp, H. 1994. Four hundredmillion-year-old vesicular arbuscular mycorrhizae. Proc. Natl. Acad. Sci. USA 91:11841-11843.

Rhodes, M. J. C. 1994. Physiological roles of secondary metabolites in plants: Some progress, many outstanding problems. Plant Mol. Biol. 24:1-20.

Simard, J., Michaud, D., Gauthier, S., Singh, S.M., Mérand, Y., and Labrie, F. 1996. Characterization of the effect of the novel antiestrogen EM-800 on the basal and estrogen -induced proliferation of T-47D, ZR-75-1 and MCF-7 human breast cancer cells in vitro. Page 605, P2804 in: Int. Congr. Endocrynol., 10th.

Simon, L., Bousquet, J., Lévesque, R. C., and Lalonde, M. 1993. Origin and diversification of endomycorrhizal fungi and coincidence with vascular land plants. Nature 363:67-69.

Siqueira, J. O., Safir, G. R., and Nair, M. G. 1991. Stimulation of ve- sicular-arbuscular mycorrhiza formation and growth of white clover by flavonoid compounds. New Phytol. 118:87-93.

Stachel, S. E., Nester, E. W., and Zambryski, P. 1986. A plant cell factor induces Agrobacterium tumefaciens vir gene expression. Proc. Nat. Acad. Sci. USA 83:379-383.

Tsai, S. M., and Phillips, D. A. 1991. Flavonoids released naturally from alfalfa promote development of symbiotic Glomus spores Appl. Environ. Microbiol. 57:1484-1488.

Vierheilig, H., Bago, B., Albrecht, C., Poulin, M. J., and Piché, Y. Flavonoids and arbuscular mycorrhizal fungi. In: Flavonoids and Related Compounds. B. S. Buslig and J. A. Manthey, eds. Am. Chem. Soc. Symp. Ser., Orlando, FL. (In press.)

Vogt, T., Pollack, P., Tarlyn, N., and Taylor, L. P. 1994. Pollination or wound-induced kaempferol accumulation in Petunia stigmas enhances seed production. Plant Cell 6:11-23.

Watrud, L. S., Heithaus, J. J., III, and Jaworski, E. G. 1978 Geotropism in the endomycorrhizal fungus Gigaspora margarita. Mycologia 70: 449-452.

Whitten, P. L., and Naftolin, F. 1991. Dietary estrogens: A biologically active background for estrogen action. Pages 155-167 in: The New Biology of Steroid Hormones. R. Hochberg and F. Naftolin eds. Raven Press, New York. 